\title{
Toxic splash: Russian rocket stages dropped in Arctic waters raise health, environmental and legal concerns
}

\section{Michael Byers}

Professor and Canada Research Chair in Global Politics and International Law, Department of Political Science, University of British Columbia, 1866 Main Mall - C425, Vancouver, BC, V6T 1Z1, Canada (michael.byers@ubc.ca)

\section{Cameron Byers}

\author{
Gulf Islands Secondary School, 112 Rainbow Rd, Salt Spring Island, BC, V8K 2K3, Canada
}

Received March 2017; first published online 2 October 2017

\begin{abstract}
Russia has dropped rocket stages fuelled with unsymmetrical dimethylhydrazine (UDMH) into the Barents Sea and the North Water Polynya - areas of considerable ecological importance — on ten occasions since 2002. The stages come from SS-19 intercontinental missiles that have been re-purposed for launching satellites. UDMH is a highly toxic chemical that has caused widespread health and environmental damage in Kazakhstan and Russia as a result of its extensive use there as a rocket fuel. Not all of the fuel on-board is consumed during a launch and the residual fuel tends to escape the incoming stages and form aerosol clouds that drift over large areas. This dropping of the rocket stages is of considerable concern to the Inuit of Canada and Greenland, who only learned about the practice in 2016. It is also a violation of several treaties as well as customary international law. At least two more launches of UDMH-fuelled rockets on the same trajectory are currently planned-even though alternative non-toxic rocket systems exist.
\end{abstract}

\section{Introduction}

Looking skyward at midday on 16 February 2016, a US serviceman at Thule Airbase in northwest Greenland shot a brief amateur video that is readily available on YouTube (Pika, 2016). In the video, a bright light appears in the sky, moving downward and quickly westward. The light then separates into two parts, the first of which stops moving. The second continues to descend toward the west, before both fade from view. The fast-moving light was the second stage of a 'Rockot'-a modified SS-19 intercontinental ballistic missile (ICBM) used by Russia to launch mid-sized satellites into orbit. By the time it faded, it was in the final moments of suborbital atmospheric re-entry. As will be explained in this paper, the separation of the light into two parts suggests that the integrity of the stage had been compromised, with the stationary part likely to be a cloud of released residual rocket fuel reflecting the midday Arctic sunlight. Rocket stages used for satellite launches rarely consume all of their fuel before they are shut down after reaching the desired speed and altitude. In February 2016, the residual fuel in the second stage of the Rockot would have vaporised on contact with the air and drifted downwards over Greenland and Canada's Ellesmere Island, or Baffin Bay. This situation demands attention because the first two stages of Rockots are powered by unsymmetrical dimethylhydrazine (UDMH), a highly toxic chemical that has caused widespread health and environmental damage in Kazakhstan and Russia (Fedorov, 1999; Giles,
2005; UNDP, 2004). Much of that damage has occurred because the residual fuel is often converted into a drifting aerosol as the integrity of the incoming rocket stages are compromised (Carlsen, Kenesova, \& Batyrbekova, 2007).

This article has ten parts: Part I describes the characteristics of the Rockot launch vehicle, the reasons why the first and second stages are dropped in the Barents Sea and Baffin Bay, respectively, and why some UDMH remains on-board the stages after they have fulfilled their missions and are plummeting back to Earth. Part II describes the ecology of the Barents Sea and, especially, northern Baffin Bay. Part III elaborates on the toxic nature of UDMH. Part IV then reviews the limited literature on the health and environmental risks of UDMH, which mostly concerns the effects of residual rocket fuel in Kazakhstan and Russia. Part V is devoted to the interests of the Inuit, the indigenous people of the Canadian Arctic and Greenland. Part VI describes the reaction of the Canadian government to the Russian use of Baffin Bay as a disposal site for UDMH-fuelled rocket stages, while Part VII describes the Russian government's response. Part VIII explains why Russia's actions violate international law, and why the European Space Agency, the Netherlands, France and other member states of the European Space Agency could also be legally responsible. Part IX then explains why the use of UDMH as rocket fuel is declining around the world, before Part X makes recommendations as to how the different countries involved might address the risks identified in this article. 
Given the multidimensional aspects of the situation, this article necessarily draws upon a number of specialised fields, including rocket science, chemistry, oceanography, international law and international relations.

\section{Rockot}

A Rockot launch vehicle is $2.5 \mathrm{~m}$ in diameter and $29 \mathrm{~m}$ long, with the UDMH-fuelled first and second stages being $17.2 \mathrm{~m}$ and $3.9 \mathrm{~m}$ long (Space Launch Report: Rockot/Strela, n.d.). Russia re-purposes SS-19s into Rockots because it has a stockpile of them left over from the 1980s (Bergin, 2015). Using re-purposed missiles enables Russia to compete in the commercial space launch market, which yields foreign currency. They also provide low-cost launches for Russian military satellites. The February 2016 launch took place at Plesetsk Cosmodrome, $800 \mathrm{~km}$ north of Moscow, in order to put a European Space Agency satellite into orbit. Commercial launches using modified SS-19s are provided by Eurockot Launch Services, which is a joint venture of ArianeGroup and Khrunichev Space Centre, a Russian state-owned company (Eurockot, n.d.). When the payload is a military satellite, the launch is conducted solely by Khrunichev Space Centre.

The trajectory of each Rockot is determined by the desired orbit. In the case of the February 2016 launch this was a 'sun-synchronous orbit' in which each pass of the satellite takes it over the same points on the planet's surface at the same local solar time. The consistent lighting provided by a sun-synchronous orbit makes it ideal for Earth imaging and weather satellites. During the launch, each stage of the Rockot is shut down by on-board computers at predetermined points (Zak, 2005). The first stage, fairings (the cone-shaped structure that protects the satellite during the initial stage of the launch) and second stage are detached and fall to Earth without going through a full atmospheric re-entry. The third stage is discarded once orbit is achieved. In order to ensure they reach their intended points, the stages carry additional fuel reserves of approximately $5-10 \%$ of the total propellant load, which is up to 71.45 tonnes for the first stage and 10.71 tonnes for the second stage (Space Launch Report: Rockot/Strela, n.d.). This means that between them, the two stages could contain as much as eight tonnes of residual fuel as they fall to Earth.

The precision of a successful launch means that the locations of the 'debris fields' for the first two stages and the fairings can be determined with some accuracy. When a Rockot is used to launch a satellite into sun-synchronous orbit from Plesetsk, the first stage falls into the Barents Sea, approximately $150 \mathrm{~km}$ north of the Varanger Peninsula, west of the maritime boundary between Norway and Russia (Nilsen, 2016). The fairings fall further to the northwest, within the Norwegian exclusive economic zone south of Bear Island. The second stage falls in northern Baffin Bay. We know this because in advance of each launch the Russian government provides the coordinates of the debris field for the purposes of a 'notice to airmen' (NOTAM) which is issued, in this case, by air traffic control in Iceland (NOTAM, 2016). The debris field for the second stage is located between, but not infringing on, the 12 nautical mile territorial sea of Canada and the three nautical mile territorial sea of Greenland. The avoidance of the territorial seas is probably deliberate, given the technological strength of the Russian space programme. The NOTAMs make no mention of any risk from residual fuel in the returning stages. Inuit living near the debris field in Baffin Bay, and who often travel there while hunting, do not receive notice from any source (CBC Radio, 2016; Hannestad, 2016; Weber, 2016b).

Another launch to sun-synchronous orbit, this time of a military satellite, took place on 4 June 2016-four months after the launch captured on video (Weber, 2016a). Ten Rockot launches have taken place on the same trajectory in the last 15 years: 17 March 2002, 30 June 2003, 30 October 2003, 26 August 2005, 28 July 2006, 17 March 2009, 2 November 2009, 2 June 2010, 22 November 2013, 16 February 2016 and 4 June 2016 (Space Launch Report: Rockot/Strela, n.d.).

At least two more launches on a Rockot into sunsynchronous orbit are currently planned from Plesetsk in late 2017 and early 2018. Both satellites are part of the Copernicus programme of Earth observation, which is 'headed by the European Commission [...] in partnership with the European Space Agency' (European Space Agency, Copernicus, n.d.). Sentinel-5P, 'a joint initiative between ESA and the Kingdom of the Netherlands, represented by the Netherlands Space Office' (European Space Agency, Sentinel-5P, n.d.), is due for launch in mid-October 2017, after a delay of several years (European Space Agency, Sentinel-5P Launch Campaign, n.d.). Sentinel-3B, which centrally involves the French Space Agency, the Centre National d'Etudes Spatiales (CNES, n.d.), is scheduled for launch in 2018 (European Space Agency, Sentinel-3B, n.d.). As before, these two launches will result in rocket stages and residual fuel falling into the Barents Sea and Baffin Bay.

\section{Ecology of the Barents Sea and Baffin Bay}

The Barents Sea remains ice-free throughout the year due to the warming effect of the Gulf Stream. The absence of sea ice allows for an early and very large plankton bloom which supports the world's largest cod fishery (Hønneland, 1999). Since 1975, the fishery has been successfully co-managed by Norway and the Soviet Union/Russia (Norway \& USSR, 1975). A Joint Fisheries Commission, relying on scientific advice from the International Council for the Exploration of the Sea, recommends annual 'total allowable catches' that are divided between the two countries (Norwegian Ministry of Fisheries and Coastal Affairs, n.d.). The debris field for the incoming first stages of Rockots used to launch satellites into 
sun-synchronous orbit from Plesetsk is located in the middle of this fishery.

As for the second stages, the co-ordinates in the NOTAM coincide with the location of a major 'polynya'a Russian word for an area of year-round open water in an otherwise ice-covered sea-located in northern Baffin Bay. The North Water Polynya is the largest in the circumpolar Arctic (Barber, Marsden, \& Minnett, 2001; WWF Greenland, 2015). Covering 80,000 km² at its maximum in late winter, it is a consequence of three factors: (1) a confluence of currents-the West Greenland Current bringing warmer water up the coast of Greenland and the Baffin Current bringing colder water down the coast of Ellesmere Island-causes considerable upwelling (Tang, Ross, Yao, \& Dunlap, 2004); (2) an ice bridge forms in winter across Kane Basin, at the northern end of the area, preventing the southward flow of ice (Dumont, Gratton, \& Arbetter, 2009); and (3) prevailing winds and currents push any ice that encroaches into the area southwards, away from the ice bridge (Dumont et al., 2009).

From an ecological perspective, polynyas are probably of critical importance. The North Water Polynya is the most biologically productive location in the circumpolar Arctic (Deming, Fortier, \& Fukuchi, 2002), with the mixing of currents and absence of sea ice creating a serendipitous combination of nutrients, aeration and solar input for an early and very large plankton bloom (Tremblay et al., 2006). This high primary production supports an abundance of Arctic cod, which in turn supports large numbers of marine mammals and seabirds (HeideJorgensen et al., 2013). The absence of sea ice also enables marine mammals and seabirds to survive much further north during winter than would otherwise be possible (Stirling, 1980). Most of the world's narwhal use the North Water Polynya, along with approximately 14,000 beluga whales and 1,500 walrus (WWF Greenland, 2015). Large numbers of bowhead whales, polar bears, and bearded, harp, hooded and ringed seals also frequent the polynya. Furthermore, the North Water Polynya supports the largest single-species aggregation of seabirds in the world: a colony of 60 million little auks near Qaanaaq, Greenland (WWF Greenland, 2015). It is also home to significant populations of common eiders, thick-billed murres, blacklegged kittiwakes, ivory gulls, Arctic skuas, Arctic terns, alcids and northern fulmars. Given this concentration of biota, the North Water Polynya is an inappropriate location for dropping rocket stages with toxic residual fuel on-board.

\section{Unsymmetrical dimethylhydrazine}

As Fedorov (1999, p. 157) explained:

Multi-stage space missiles are a serious concern because they drop first and second stage vehicles, containing various quantities of unused propellant, to the surface of the Earth. At impact sites, there may be serious ecological and human health impacts.
The first and second stages of Rockots are of particular concern because they are fuelled with UDMH, referred to as 'heptyl' in Russia. The chemical, which has the formula $\left(\mathrm{CH}_{3}\right)_{2} \mathrm{NNH}_{2}$, was chosen by the Soviet Union for ICBMs because it is stable at ambient temperatures, enabling missiles to be filled with the propellant and left in their launch tubes for years (Schmidt, 1984). The stability of UDMH, along with its easy ignition and high-energy production, also made it attractive to other missile and space programmes. It was used to power US Titan rockets, Chinese Long March rockets, the Soviet/Ukrainian Tsyklon rocket, the Soviet/Russian Kosmos and Proton rockets, the European Ariane 1, 2, 3 and 4 rockets, and parts of the Indian Geosynchronous Satellite Launch Vehicle, as well as the recently developed Geosynchronous Satellite Launch Vehicle Mark III (Turner, 2009).

More recently, concerns about the toxicity of UDMH have led to reductions in its use as a rocket fuel, with nontoxic fuels such as kerosene, liquid oxygen and hydrogen serving as replacements (Turner, 2009). As detailed below, the USA, Europe and Japan have already replaced UDMH as a launch fuel, while China and Russia are in the process of doing so. The only country that seems set on UDMH, at least for the moment, is India.

A related chemical, monomethylhydrazine $\left(\mathrm{CH}_{3}(\mathrm{NH}) \mathrm{NH}_{2}\right)$, is used as a storable liquid propellant to operate the repositioning thrusters and auxiliary power units on satellites and other spacecraft, and will probably remain in use until a suitable replacement for these purposes is found. Efforts to find such a replacement are underway, again, because of concerns about toxicity (de Selding, 2016; Leonard, 2016; NASA, n.d.). The risk posed by monomethylhydrazine was highlighted in 2008 when the USA deployed a missile defence interceptor to destroy a defective satellite loaded with the propellant before it could re-enter the atmosphere and crash. In advance of the strike, the Federal Emergency Management Agency issued a public warning:

Any debris should be considered potentially hazardous, and first responders should not attempt to pick it up or move it (Shanker, 2008).

As the following section of this article shows, the use of UDMH as rocket fuel has caused considerable health and environmental damage in Kazakhstan and Russia. However, there is no scientific literature on the effects of UDMH in the oceans generally or specifically in the conditions prevalent in the Barents Sea and the North Water Polynya.

\section{Health and environmental effects of UDMH}

Few studies of the human health effects of UDMH have taken place in Western countries. In 1999, a 'retrospective cohort study' of 6,107 US aerospace workers examined 'whether exposure to chemicals-primarily hydrazine fuels - during rocket-engine fueling and testing affects cancer mortality' (Ritz, Morgenstern, Froines, \& Moncau, 1999, p. 903). It found that exposed workers 
were 1.68-2.10 times more likely to die from lung cancer than unexposed workers, with the variations in likelihoods being related to the length of time in the job and the postexposure interval. Increased likelihood of death due to haemato and lymphopoietic cancers, as well as bladder and kidney cancer were also reported in this study, although these relationships were less precise.

In 2004, an article in Military Medicine explained:

The excellent high-energy combustion created by hydrazine fuels is always balanced with its toxicity. Hydrazine fuels are known to cause cancer after respiratory exposure or ingestion in laboratory animals and humans (Helmers, Ruland, \& Jacob, 2004, p. 41). The authors wrote that their own research into a cancer in a US Air Force employee exposed to UDMH

[S] upports ongoing government efforts to find alternative fuels and to increase personal protection for workers exposed to hydrazine fuels (Helmers et al., 2004, p. 41).

Furthermore, US Air Force personnel who worked with Titan II nuclear missiles insist that their exposure to UDMH and its derivatives has caused many serious health problems (Titan II Missile Veterans Health and Wellness, n.d.).

Most of the literature on the health and environmental effects of UDMH comes from Kazakhstan and Russia because of a decades-long practice of dropping rocket stages on land in those countries (Fedorov, 1999). Hundreds of Soviet and Russian launches at Baikonur Cosmodrome in Kazakhstan have been powered by this fuel (UNDP, 2004). Depending on the trajectory of the launch, the first stages of the rockets land in either northeastern Kazakhstan or southern Russia. As Fedorov (1999, p. 158) reported:

Analysis of ecosystems (unpublished data) at sites of fall of the first stages of Tsyklon-3, Kosmos-3M, and Proton space missiles have revealed vast territories polluted by the toxic propellant and its metabolites. The chemicals were found in vegetation, soil and sediments, subsoil and surface waters, at concentrations far in excess of those permissible according to the Russian hygienic standards. There also exists the possibility of long-range atmospheric transport of UDMH aerosols from falling stages of missiles. Those aerosols could affect natural ecosystems, crop plants, agricultural animals and humans at depositional sites.

A United Nations Development Program report (UNDP, 2004) on the Environment and Development Nexus in Kazakhstan constitutes the most detailed examination of the effects of UDMH-fuelled rocket stages in that country. It begins by identifying the geographical scope of the problem:

$[\mathrm{T}]$ he products of combustion and non-combusted remains of fuel and oxidants falling from the height of 20-100 kilometers spread and land over thousands of square kilometers... By their ecological condition the fall areas are referred to as 'zones of ecological disaster', while impact zones are 'zones of ecological crises'. According to expert evaluation their total area constitutes 77.09 million hectares (UNDP, 2004, pp. 50-51)

The amount of UDMH involved is significant, with more than 2,000 tonnes having been released from 1957-2000 as the result of launches from Baikonur (UNDP, 2004). Again, some of the pollution comes via the air, since the integrity of a rocket stage can become compromised during its plunge toward Earth, releasing the residual fuel and creating a long aerosol trail (UNDP, 2004).

The report, which refers to UDMH as 'heptyl', explains that the chemical persists on land and in freshwater ecosystems:

This toxicant is hazardous when it gets into the environment due to its volatility, unlimited solubility in water, ability to migrate and accumulate in soils, solid soils, in silt precipitations of reservoirs and rivers, in organisms of plants and animals, due to its stability in deep layers of soil, as well as in plants, silts and in mineral oil... The self-purification period of lands from heptyl is about 34 years ... (UNDP, 2004, p. 53). The report also explains the effects of UDMH on human health:

Heptyl is dangerous in all methods of transmission to people: through the digestive system, respiratory organs, skin and lymphatic system. Clinically, if poisoned by UDMH, the following occurs: increased excitement, breath disturbance, convulsions, functional changes in the central nervous system, kidney and liver failure and peripheral blood composition changes. Once in an organism, UDMH gets quickly absorbed and distributes evenly in the tissues and organs; it is secreted through the kidneys and lungs, possibly with milk (UNDP, 2004, p. 87).

The UNDP report is based on medical studies involving 48,000 people, including 16,500 children, in areas where two Proton rockets crashed in 1999. The children had a 'high frequency of pathology in physical development' (UNDP, 2004, p. 88). Eighty-three percent of infants suffered from rickets, with anaemia, weakened immune systems and high rates of urinary tract and thyroid disease present across all age groups. Only $26.5 \%$ of the adults could 'be characterized as healthy people, the rest had various types of pathological illnesses' (UNDP, 2004, p. 89), with high levels of cardiovascular illnesses, skin and breast cancer, throat, stomach and lung disease. All these health problems were linked to a decrease in the birth rate in the affected areas.

In 2005, Nature reported on an unpublished study from the State Research Centre of Virology and Biotechnology in Novosibirsk, Russia (Giles, 2005). The study compared children living in areas of southern Russia polluted with UDMH from launches in Baikonur with children living in nearby unpolluted areas. The children in polluted areas were more than twice as likely to have diseases such as endocrine and blood disorders. Also in 2005, the Russian news agency RIA Novosti reported:

The Northern Medical University, having studied the effect of liquid propellant components on human 
health where heptyl was in operation as rocket fuel, warns that the death rate in affected areas has risen by $30 \%$, mostly due to liver, blood and genetic diseases. However, it has so far failed to draw a direct link from the launches to the deaths. Experts say additional studies are necessary to come to any definite conclusions (RIA Novosti, 2005).

Carlsen et al. (2007) reported that UDMH was found in the soil at more than 1,000 sites where used rocket stages had dropped more than 20 years previously, and that UDMH constitutes a substantial threat to both the environment and human health. Human health risks were attributed to the carcinogenic, mutagenic, convulsant, teratogenic, embryotoxic and other general toxic characteristics of UDMH. They further reported that contamination with UDMH starts already during the falling of used stages of rockets, sometimes at heights as high as $10 \mathrm{~km}$ above ground level. The result of this is that large amounts of unburned fuel are distributed atmospherically over multiple square kilometres of land. People are therefore directly exposed to UDMH during the actual fall of the used stages, while long-term indirect exposure may be attributed to UDMH being volatised from contaminated soil (Carlsen et al., 2007).

A follow-up study, published the next year, examined 18 'transformation products' that are formed directly from UDMH when it is released into the environment or through subsequent processes (Carlsen, Kenessov, \& Batyrbekova, 2008). It reported that:

Substances with an intact hydrazine structure or hydrazones display a toxicity that indicate that transformation products of these types may contribute to the overall environmental toxicity of residual rocket fuel and its transformation products as these compounds display toxicities comparable or even higher than the toxicity of the primary pollutant (Carlsen et al., 2008, p. 19).

Specifically, these substances are tetramethylhydrazine, acetaldehyde dimethylhydrazone, formaldehyde dimethylhydrazone, trimethylhydrazine and 1-formyl 2,2dimethylhydrazine.

Moreover, some of these substances persist longer in the environment than UDMH; for example, 1-formyl 2,2dimethylhydrazine has a half-life of 2,220 years in lakes (Carlsen et al., 2008). It is therefore possible that UDMH released into the air or water, or landing on sea ice, could be transformed into chemical derivatives posing risks to human health and the environment that are not only serious but longer lasting than those posed by UDMH alone.

Health effects from launches at Plesetsk have also been studied. Fedorov (1999, p. 159) conveyed some findings from the 1995 annual report of the Russia State Ecological Committee, including maximum concentrations of UDMH of $47 \mathrm{mg} / \mathrm{kg}$ (466 units of the Russian hygienic standard) in vegetation and $268 \mathrm{mg} / \mathrm{kg}$ (2,684 units of the Russian hygienic standard) in soils in the Koida region, and $24 \mathrm{mg} / \mathrm{l}$ of UDMH (1,200 units of the Russian hygienic standard) in subsoil waters of Narjan Mar. Fedorov (1999, p. 159) also reproduced the conclusions from the 1996 annual report of the Russia State Ecological Committee, including that 'intensive atmospheric transport of pollutants' can occur for several hours after a rocket stage returns to Earth and human populations should be evacuated from these areas during launches 'because of toxicity of propellant and the danger of human exposure'.

Most significantly, Fedorov (1999) reported on a study by Minjaev, Sidorov, \& Sovershaeva (1997) on the health of residents of two villages exposed to UDMH from rocket stages launched from Plesetsk. In the first village, 90\% of the inhabitants displayed pathologies; in the second village, $79 \%$. In both villages, more than $50 \%$ of the inhabitants had liver damage. There were also high frequencies of damage to the hepatobiliary system, and of anaemias, leuco/lymphopenias and toxic eosinophilia. According to Fedorov (1999, p. 159), the study concluded that living in the 'zone of influence' of Plesetsk Cosmodrome caused 'an increased risk of vegetative-asthenic brain syndrome, intoxication of unknown genesis, functional hepatic insufficiency, and morphological changes of the liver's structure'.

Finally, RIA Novosti (2005) reported on how villagers near Plesetsk make a living off salvaging debris. The first stages of Soyuz rockets have a 'reputation for safety' because they are powered by kerosene and liquid oxygen, whereas

[o]lder Tsiklon and Rockot carriers propelled by poisonous heptyl leave scraps that people avoid for the time being. 'Self-cleaning', as locals put it, is just a matter of years for them, after which the metals are considered safe to extract.

As for the environmental impacts, aquatic organisms are particularly susceptible to UDMH, as New Scientist reported in 1993:

In some lakes in the Kanin peninsula fish have been dying in vast numbers. "Archangel is in the flight path of rockets launched from Plesetsk and the first stages fall to Earth in this area,' explains Victor Kuznetsov of the Archangel Ecology Committee. 'These still contain some liquid fuel which is very toxic' (Perera, 1993).

However, there is no scientific literature on the effects of UDMH in marine ecosystems. Water in the oceans is very different from the water found in most freshwater lakes and rivers, in terms of salinity, $\mathrm{pH}$, oxygen content, etc. Even if such scientific studies did exist, they might be of limited applicability to the North Water Polynya, where the water is unusually low in temperature, salinity and $\mathrm{pH}$ - partly as a result of considerable melting from sea ice, icebergs and nearby glaciers (Barber et al., 2001).

\section{Inuit interests}

The North Water Polynya's abundance of wildlife is critically important to the Inuit, the indigenous people of the Canadian Arctic and Greenland. In their language, 
Inuktitut, the North Water Polynya is called 'Pikialasorsuaq'-the great upwelling. Hunters from Canadian communities, such as Grise Fiord and Pond Inlet, travel to the ice-edge regularly, as do hunters from Greenlandic communities, such as Avanersuaq. In 2016, media reports illustrated opposition to the returning rocket stages from the Inuit Circumpolar Council and the Community and Government Services Department in Nunavut (Weber, 2016b). Furthermore, reports suggested that local communities and organisations had never been informed of rocket stages landing in the area (CBC Radio, 2016; Hannestad, 2016). At the time, the Inuit were reacting to the news that UDMH might land in the water or on sea ice. They were probably unaware that the greatest risk from the returning rocket stages might come from aerosol trails of UDMH and transformation products; trails that could drift, not just onto hunters on the sea ice but their home communities also. The video taken from Thule Airbase in February 2016 would seem to confirm the existence of this risk.

Coincidentally, in January 2016 the Inuit of Canada and Greenland had established a 'Pikialasorsuaq Commission' composed of Okalik Eegeesiak, former Nunavut Premier Eva Aariak, and former Greenland Premier Kuupik Kleist (Inuit Circumpolar Council, 2016). During its first year, the Commission conducted hearings on both sides of the polynya regarding community concerns and aspirations. It found that wildlife remains the most important food source for the people living nearby and that the area is threatened by climate change and the possibility of increased shipping, tourism, fishing and non-renewable resource development (Nunatsiaq News, 2016). The Commission also reported that Inuit in Canada and Greenland strongly desired Inuit-led protection and management of the North Water Polynya (Nunatsiaq News, 2016). Such an Inuit-led regime for ecosystem management is certainly possible, for instance, if Canada and Denmark were to create a binational marine protected area and assign responsibility for its administration to the governments of Nunavut and Greenland. It is difficult to imagine such an Inuit-led management regime approving the use of the North Water Polynya as a disposal area for UDMH-fuelled rocket stages, at least in the absence of scientific proof as to their harmlessness. Although a large marine protected area was announced for Lancaster Sound in August 2017, it neither encompasses the North Water Polynya nor assigns administrative responsibility to Inuit (Parks Canada, n.d.).

\section{Canadian government reaction}

Russia informs Canada several weeks before dropping any rocket stage into Baffin Bay and, at least some of the time, Canada responds with a diplomatic protest. The Canadian newspaper La Presse obtained documents showing how, in both October 2009 and June 2010, Russia informed Canada that debris would fall into northern Baffin Bay (Bellavance, 2010). Although Canada issued protests, the launches went ahead (Bellavance, 2010). The first was of two European Space Agency satellites; the second of a single satellite from Japan. Both launches were conducted from Plesetsk using UDMH-fuelled Rockots. The documents contained a briefing note prepared for Canada's minister of foreign affairs that stated:

Canada made Russian officials aware of its concerns. Canada hopes that the two countries will be able to rapidly find a solution that is satisfactory to them (Bellavance, 2010, my translation).

According to the minister's spokeswoman, Canada also shared its concerns with Japan in advance of the 2010 launch-again, to no avail. But as the spokeswoman assured La Presse:

As far as concerns this particular case, as we do not possess indications that damage would be caused to Canadian territory, we continue to follow the situation closely (Bellavance, 2010, my translation).

It is unclear whether any protest was issued before the February 2016 launch. But when the Canadian Press contacted the government in advance of the June 2016 launch, a spokesman for Global Affairs Canada replied:

The Government of Canada has sought clarification from the Government of Russia regarding the lack of sufficient notification of this rocket launch. We have stressed to the Government of Russia the need for greater advance warning of planned launches to ensure that all precautions, relating both to the safety and security of our airspace and any potential environmental concerns, can be appropriately addressed (Weber, 2016a).

The spokesman also said that the fuel in the rocket stage was expected to burn completely during re-entry and that the Canadian government therefore expected 'minimal environmental risks' (Weber, 2016a). Nevertheless, he stated:

We have also urged in certain terms that the Russian government make every effort to ensure that debris does not land on Canadian soil or within our exclusive economic zone. This issue is governed by a number of international treaties. Canada expects Russia to fully comply with its obligations in this regard (Weber, 2016a).

\section{Russian government response}

In June 2016, Kirill Kalinin, press secretary at the Russian embassy in Ottawa, told the Canadian Press:

With regard to the inquired rocket launch, the Canadian side was informed it would be done in a way that no territory of Canada or its territorial waters would be affected while the fuel of disposed rocket stages fully burn out. In this context environmental concerns are seriously taken into account (Weber, 2016a).

However, as detailed earlier, there are good reasonsincluding the video from Thule Airbase in February 2016, and the widespread health and environmental damage caused by UDMH-fuelled rocket stages elsewhere-to 
believe that there was residual fuel in the returning rocket stage and some of it survived the suborbital flight, most probably dispersing into the air before falling into the water or onto the surrounding ice and land.

It is also noteworthy that the Russian press secretary used the term 'territorial waters' rather than 'exclusive economic zone', as the Canadian spokesman did. According to the NOTAM, the debris field was located entirely within the exclusive economic zones of Canada and Greenland, extending right up to but not infringing upon, their respective 12 and 3 nautical mile territorial seas. The Russian press secretary chose his words carefully and accurately. Nevertheless, as Canada recognised (and as will be explained below) dropping the rocket stage in the exclusive economic zone was still a violation of international law.

The Russian government response is unsurprising, since it has also refused to acknowledge UDMH pollution as a problem in Kazakhstan and Russia. When asked about the issue by the BBC in 2013, Anatoly Kuzin, deputy director of the Khrunichev Space Centre that launches Rockots, insisted:

There is no data to prove any link between the illnesses and the influence of rocket fuel components or space activity of any kind.

Kuzin also said that the Russian Space Agency conducts research constantly and no significant level of toxicity has ever been found in the areas where the rocket stages land (Vassilieva, 2013). As Kuzin may have realised, any admission on his part of the health and environmental damage caused by UDMH-fuelled rockets could facilitate the establishment of causation and thus 'state responsibility', that is, liability in international law.

\section{Legal issues}

The use of the Barents Sea and the North Water Polynya as disposal sites for UDMH-fuelled rocket stages is inconsistent with the 1982 United Nations Convention on the Law of the Sea, a treaty which Canada, Denmark, Norway and Russia have all ratified (UNCLOS, 1982). The provision most directly applicable is Article 212(1) on Pollution from or through the atmosphere, which reads, in part:

States shall adopt laws and regulations to prevent, reduce and control pollution of the marine environment from or through the atmosphere, applicable to the air space under their sovereignty and to vessels flying their flag or vessels or aircraft of their registry, taking into account internationally agreed rules, standards and recommended practices and procedures and the safety of air navigation (UNCLOS, 1982, emphasis added).

Since the rockets used by Russia for satellite launches are vessels of their registry-as required by the Convention on Registration of Objects Launched into Outer Space (Registration Convention, 1975)—-the Russian government has the obligation to 'prevent, reduce and control pollution of the marine environment' from them.

With regards to the North Water Polynya specifically, Canada and Denmark both have extensive rights with regards to any pollution risk there. Article 234 of UNCLOS states, in full:

Coastal States have the right to adopt and enforce nondiscriminatory laws and regulations for the prevention, reduction and control of marine pollution from vessels in ice-covered areas within the limits of the exclusive economic zone, where particularly severe climatic conditions and the presence of ice covering such areas for most of the year create obstructions or exceptional hazards to navigation, and pollution of the marine environment could cause major harm to or irreversible disturbance of the ecological balance. Such laws and regulations shall have due regard to navigation and the protection and preservation of the marine environment based on the best available scientific evidence (UNCLOS, 1982).

All parts of the North Water Polynya lie within 200 nautical miles of either Canada or Greenland, which means that it-as well as, coincidentally, the debris field for the second stages of the Rockots-fall within the exclusive economic zones of those two countries. There are no 'high seas' in northern Baffin Bay, which has been bisected by an agreed maritime boundary since 1973 (Byers, 2013). The rights recognised in Article 234 are exercised by the Canadian government through the 1970 Arctic Waters Pollution Prevention Act, Section 4(1) of which reads:

$[\mathrm{N}]$ o person or ship shall deposit or permit the deposit of waste of any type in the Arctic waters... (AWPPA, 1970).

Russia might argue that Article 234 does not apply to the North Water Polynya because it is not ice-covered for most of the year. Such an argument would encounter the problem that the polynya is surrounded by sea ice and acts as an attractor for wildlife from those ice-covered areas. Denying the applicability of Article 234 to a polynya would contradict the object and purpose of this provision, which is to protect the fragile ecosystems that exist on, under and around sea ice, as well as the object and purpose of UNCLOS more generally. The importance of 'object and purpose' to treaty interpretation is set out in the Vienna Convention on the Law of Treaties (1969, Art. 31). Moreover, Russia has regulations similar to the Arctic Waters Pollution Prevention Act that it adopted pursuant to Article 234 of UNCLOS. These regulations apply along all of Russia's Arctic coastline, including a number of polynyas as well as the far western section which is icefree for most of the year (Franckx, 2009).

Even if there are areas where Article 234 might not apply-for example, in the southern ice-free portion of the Barents Sea where the first stages of the Rockots come down-Article 194(2) will apply nevertheless. It reads:

States shall take all measures necessary to ensure that activities under their jurisdiction or control are so 
conducted as not to cause damage by pollution to other States and their environment, and that pollution arising from incidents or activities under their jurisdiction or control does not spread beyond the areas where they exercise sovereign rights in accordance with this Convention (UNCLOS, 1982).

The same rule- that a state causing transboundary pollution is responsible for any harm which results, either directly or indirectly-is well established in customary international law (Birnie \& Boyle, 2002), an unwritten body of rules which often exist in parallel to treaty obligations (Baxter, 1970). Moreover, there is a treaty that applies specifically to damage caused by the return of objects launched into space, namely the Convention on International Liability for Damage Caused by Space Objects (Liability Convention, 1971). Article II reads:

A launching State shall be absolutely liable to pay compensation for damage caused by its space object on the surface of the Earth or to aircraft in flight.

Article I (d) specifies that the term 'space object' includes 'component parts of a space object as well as its launch vehicle and parts thereof'. The first and second stages of a Rockot constitute space objects for the purposes of the Liability Convention.

Russia, and before it the Soviet Union, have complied with the Liability Convention on several occasions. In 1978, the nuclear-powered Cosmos 954 satellite crashed to Earth, scattering radioactive debris across northern Canada. Although the Soviet Union denied liability, it paid Canada \$3 million (Canada-USSR Protocol, 1981). In 1999, Russia paid compensation to Kazakhstan after a Proton rocket exploded shortly after launch, spreading UDMH over the Karaganda Region (Sievers, 2003). In 2006, after another failed launch, the Russian Space Agency said it would compensate Kazakhstan for any environmental damage (Radio Free Europe, 2006).

The next stage in this legal analysis concerns the 'precautionary principle', defined in Principle 15 of the Rio Declaration as:

Where there are threats of serious or irreversible damage, lack of full scientific certainty shall not be used as a reason for postponing cost-effective measures to prevent environmental degradation (Rio Declaration, 1992).

As Birnie and Boyle explain, although the precise content of the precautionary principle in customary international law remains a subject of debate:

Use by national and international courts, by international organizations, and in treaties, shows that the precautionary principle does have a legally important core on which there is international consensus that in performing their obligations of environmental protection and sustainable use of natural resources states cannot rely on scientific uncertainty to justify inaction where there is enough evidence to establish the possibility of a risk of serious harm, even if there is as yet no proof of harm (Birnie \& Boyle, 2002, p. 120).
It is difficult to prove that UDMH is causing harm to the biota in the Barents Sea and North Water Polynya, since UDMH (unlike mercury and persistent organic pollutants) does not bioaccumulate. However, proof of harm is not required before the obligation to cease an activity is engaged. It is sufficient to establish—as this article aims to do-that there is evidence of the possibility of a risk of serious harm.

One final legal issue deserves mention, namely the international obligations and potential joint liability of the European Space Agency, the Netherlands, France and other member states of the European Space Agency. The next satellite due to be launched on a Rockot, Sentinel-5P, is a joint initiative of the Netherlands and the European Space Agency. The satellite following after that, Sentinel-3B, is a joint initiative of the European Commission, the European Space Agency and France. Again, Article II of the Liability Convention establishes that

A launching State shall be absolutely liable to pay compensation for damage caused by its space object on the surface of the Earth or to aircraft in flight (Liability Convention, 1971).

Article I (c) of the same convention states that

The term 'launching State' means (i) A State which launches or procures the launching of a space object; or (ii) A State from whose territory or facility a space object is launched.

Russia is clearly a launching state, but the Netherlands (Sentinel-5P) and France (Sentinel-3B) might, given their involvement in the missions, also be considered launching states. However, the Liability Convention neither defines the term 'procures' nor is it clear whether the two national space agencies are contributing to the costs of the respective launches rather than only the development of the satellites. It is clear that the European Space Agency is a 'launching state' and therefore potentially jointly liable, for while most treaties bind only states and not international organisations, Article XX (1) of the Liability Convention reads:

In this Convention, with the exception of articles XXIV to XXVII, references to States shall be deemed to apply to any international intergovernmental organization which conducts space activities if the organization declares its acceptance of the rights and obligations provided for in this Convention and if a majority of the States members of the organization are States Parties to this Convention and to the Treaty on Principles Governing the Activities of States in the Exploration and Use of Outer Space, including the Moon and Other Celestial Bodies.

The European Space Agency formally declared its acceptance of the rights and obligations of the Liability Convention in 1976 (United Nations Treaty Series, 1977), and the majority of its members are parties to both the Liability Convention and the Outer Space Treaty. As for the member states of the European Space Agency, Article XX (3) of the Liability Convention reads: 
If an international intergovernmental organization is liable for damage by virtue of the provisions of this Convention, that organization and those of its members which are States Parties to this Convention shall be jointly and severally liable; provided, however, that:

(a) Any claim for compensation in respect of such damage shall be first presented to the organization;

(b) Only where the organization has not paid, within a period of six months, any sum agreed or determined to be due as compensation for such damage, may the claimant State invoke the liability of the members which are States Parties to this Convention for the payment of that sum.

These treaty provisions, combined with the analysis above of the potential effects of UDMH in the Barents Sea and North Water Polynya, will create legal risks for the governments of all 22 member states of the European Space Agency if the next two Rockot launches proceed.

\section{Phasing out the use of UDMH}

The USA has phased out the use of UDMH as a rocket fuel, with its last UDMH-powered launch being a Titan rocket in 2005 (Kendall \& Portanova, 2010). In advance of that launch, the USA warned Canada that the first stage of the rocket would fall off the coast of Newfoundland with up to 2.25 tonnes of residual fuel on-board (Canadian Press, 2005). Today, most US launch providers use a combination of kerosene and liquid oxygen, with the exception being United Launch Alliance, which uses hydrogen to power its Delta IV rockets (Kendall \& Portanova, 2010). Arianespace, the European launch provider, phased out the UDMH-fuelled Ariane 4 in 2003 (Space Launch Report: Ariane 4, n.d.). The Ariane 5 is fuelled by liquid oxygen and hydrogen. Arianespace also uses Russian-supplied Soyuz ST rockets, which are fuelled with kerosene and liquid oxygen, and smaller Vega rockets powered by the solid fuel hydroxyl-terminated polybutadiene. Japan stopped using UMDH in 1987 when it moved from its $\mathrm{N}$-series to its $\mathrm{H}$-series of rockets. Its newest rocket, the $\mathrm{H}-2 \mathrm{~A}$, uses a combination of liquid oxygen and liquid hydrogen along with solid fuel boosters (Japan Space Exploration Agency, 2016). For decades, China used UDMH in its Long March 2, 3 and 4 series of rockets, causing serious health and environmental damage within impact zones on Chinese territory (South China Morning Post, 2010). China has recently developed a new generation of rockets-the Long March 5, 6 and 7 series-that uses non-toxic propellants such as kerosene and hydrogen. All three of the new rocket types were brought into service in 2015-2016 (Clark, 2016b).

India continues to use UDMH exclusively, in its Geosynchronous Satellite Launch Vehicle and the recently developed Geosynchronous Satellite Launch Vehicle Mark III (Indian Space Research Organisation, n.d.). However, its rocket stages are dropped in the southern Indian Ocean, which is much deeper, larger and further from communities than the Barents Sea and the North Water Polynya.

As mentioned, Russia has commenced a move away from UDMH - in part because of concern about its effects on human health and opposition to the fuel from affected populations. In 2006, after a UDMH-fuelled Dnepr rocket crashed just one minute after lift-off from Baikonur, two members of Kazakhstan's parliament sent a letter to the country's prime minister demanding an end to the use of the chemical (Pannier, 2006). In 2014, the opposition Nationwide Social-Democratic Party of Kazakhstan called for Proton launches to be banned from Baikonur because of the damage caused by UDMH. It accused the Kazakh government of suppressing discussion of the topic and persecuting members of the 'anti-heptyl movement' (Bodner, 2014). In a 2015 interview with the official Kazakh news agency, Talgat Mussabayev, the chair of the aerospace committee of the Kazakh Ministry of Investment and Development, explained that a 2004 agreement between Kazakhstan and Russia on the Baikonur Cosmodrome included 'the creation of a new environmentally-safer space rocket system for the subsequent phase-down of exploitation of vehicles that use highly-toxic components of rocket fuel' (Turebekova, 2015). Mussabayev called UDMH a 'substance of the first class of danger' and said 'improvement of environmental performance of the fuel is not possible' (Turebekova, 2015). In 2016, the Independent Barents Observer reported that Sergey Gaplikov, the leader of the Komi Republic in northwest Russia, had written on his government website about the need to remove a 'rather significant volume' of rocket debris that 'has piled up on our territory' from the nearby Plesetsk Cosmodrome (Staalesen, 2016). The article also reported:

Local authorities and environmental groups have long called for better clean-up of the trash, which they say contaminates vulnerable northern nature and harms peoples' health (Staalesen, 2016).

Russia already has non-toxic alternatives, including its versatile Soyuz rockets which are used to launch both satellites and cosmonauts. Russia's new generation Angara rockets, one size of which is due to replace the Rockot, is likewise powered by kerosene and liquid oxygen. However, the move to the Angara-series has been delayed for several years, with one possible factor being the continued availability of SS-19s convertible to Rockots. In 2013, Markus Poetsch, Eurockot's chief technical officer, said that 80 SS-19s had been assessed and were available to the company. The availability of this hardware was credited with enabling Eurockot to maintain prices of between 30 and 32 million Euros per launch (de Selding, 2013). In June 2016, however, Space Flights News reported that Russia would make just four more launches with Rockot before moving to Angara (Space Flight News, n.d.). The same report cited a story from TASS news agency to the effect that two of the launches, involving three Russian civilian communications satellites each, had been pushed back to undetermined dates due 
to technical problems with Rockot (TASS, 2016). Space Flights News found this explanation implausible as it came just two days after the successful 4 June 2016 launch.

The two launches of European Space Agency satellites have also been delayed, and are presently scheduled for mid-October 2017 (European Space Agency, Sentinel-5P Launch Campaign, n.d.) and sometime in 2018 (European Space Agency, Sentinel-3B, n.d.). The delay caused the European Space Agency to replace Sentinel-2B with Sentinel-3B in the launch schedule for Plesetsk. The former satellite was launched on a Vega rocket from French Guiana on 6 March 2017 (Amos, 2017). On 21 June 2017, a Russian military satellite was launched into a sun-synchronous orbit from Plesetsk on a new, smaller member of the Soyuz rocket family designed to provide a mid-sized replacement for older designs such as the SS-19-derived Rockot (Graham, 2017). It was the third flight of a Soyuz-2-1v, with the first launch having taken place in 2013 (Graham, 2017). The Soyuz-2-1v is fuelled by a combination of liquid oxygen and kerosene. The June 2017 launch would, originally, have been planned for a Rockot (Graham, 2017), with the UMDH-fuelled stages dropping into the Barents Sea and the North Water Polynya.

As for the Angara, in August 2016 it was reported that the new Russian rocket had secured its first commercial customer, the South Korean Space Agency, for a 2020 launch of an Earth observation satellite into sun-synchronous orbit from Plesetsk (Clark, 2016a). The launch, again, will be a direct replacement of a Rockot that would otherwise drop UMDH-fuelled stages into the Barents Sea and the North Water Polynya.

Although impossible to verify, it is conceivable that this shift away from Rockot is now happening at least partly because of the 2016 revelation that stages with residual UDMH were being dropped in the North Water Polynya, and the subsequent engagement of the Western media, Inuit and environmental groups with the issue.

\section{Conclusion and recommendations}

In this article, the origins of UDMH-fuelled rockets, their health and environmental impacts in Kazakhstan and Russia, the particular and uncertain risks to the Arctic when Rockots are used to launch into sun-synchronous orbit from Plesetsk, the reactions of the Inuit as well as the Canadian and Russian governments, the legality of Russia using the Barents Sea and the North Water Polynya as disposal sites, and the plans for additional launches have been discussed. This section recommends how to address the risks posed by those additional launches.

\section{Recommendation 1}

The European Space Agency should stop launching satellites into sun-synchronous orbit on UDMH-fuelled rockets from Plesetsk Cosmodrome, unless and until it can be proved that UDMH poses no risk of serious harm to the Arctic environment and its peoples.

\section{Recommendation 2}

Health surveys should be conducted of Norwegian fishermen frequenting the Barents Sea and of Inuit living near the North Water Polynya to determine whether elevated rates of UDMH-related diseases are present in these populations.

\section{Recommendation 3}

The air and water in the Barents Sea and the North Water Polynya should be sampled immediately after any future launch to determine if UDMH or any of its transformation products are present.

\section{Recommendation 4}

Scientific studies, including experiments, should be conducted into the behaviour of UDMH in the conditions prevalent in the Barents Sea and the North Water Polynya, including relatively low air and water temperatures, salinity and $\mathrm{pH}$.

\section{Recommendation 5}

The European Space Agency, other space agencies, countries and companies should encourage Russia to accelerate the move to its new generation of Soyuz-2-1v and Angara rockets by contracting launches specifically on these modern non-toxic systems.

The Arctic environment faces a long list of threats, prominently including climate change and oil spills. This article illustrates the additional threat posed by UDMHfuelled rocket stages and the resulting need for ceasing the practice.

\section{References}

Amos, J. (2017, March 7). Sentinel satellite launched to picture Planet Earth. BBC News. Retrieved from http://www.bbc.co. uk/news/science-environment-39183353.

AWPPA. (1970). Arctic Waters Pollution Prevention Act. 196970 Statutes of Canada, Ch. 47, Sec 2. Retrieved from http:// laws-lois.justice.gc.ca/eng/acts/A-12/FullText.html.

Barber, D., Marsden, R., \& Minnett, P. (2001). The International North Water (NOW) Polynya Study. Atmosphere - Ocean, 39, 163-166.

Baxter, R. (1970). Treaties and custom. Recueil des Cours, 129, 27-105.

Bellavance, J.-D. (2010, November 9). Débris de fusée dans la mer de Baffin: la Russie fait fi du Canada. La Presse. Retrieved from http://www.lapresse.ca/actualites/politique/ politique-canadienne/201011/08/01-4340654-debris-defusee-dans-la-mer-de-baffin-la-russie-fait-fi-du-canada. php.

Bergin, C. (2015, September 23). Russia's Rockot launches with three Rodnik satellites. NASASpaceflight.com. Retrieved from https://www.nasaspaceflight.com/2015/09/russiasRockot-launches-three-rodnik/.

Birnie, P., \& Boyle, A. (2002). International law and the environment (2nd edition). Oxford: Oxford University Press.

Bodner, M. (2014, January 23). Toxic Russian rocket fuel target of Kazakh anger. Moscow Times. Retrieved from https://themoscowtimes.com/articles/toxic-russian-rocketfuel-target-of-kazakh-anger-31380. 
Byers, M. (2013). International law and the Arctic. Cambridge: Cambridge University Press.

Canada-USSR Protocol. (1981). Protocol between Canada and the USSR. International Legal Materials, 20, 689.

Canadian Press. (2005, June 6). Crashed U.S. rocket contained toxic chemicals (A8). Globe and Mail.

Carlsen, L., Kenesova, O. A., \& Batyrbekova, S. E. (2007). A preliminary assessment of the potential environmental and human health impact of unsymmetrical dimethylhydrazine as a result of space activities. Chemosphere, 67, 1108-1116.

Carlsen, L., Kenessov, B. N., \& Batyrbekova, S. E. (2008). A QSAR/QSTR study on the environmental health impact by the rocket fuel 1,1-dimethyl hydrazine and its transformation products. Environmental Health Insights, 1, 11-20.

CBC Radio. (2016, June 1). Russian space junk, believed to be toxic, set to splash down in Canada's Arctic. As it happens, part 3. Retrieved from http://www.cbc.ca/radio/asithappens/ as-it-happens-wednesday-edition-1.3610810.

Clark, S. (2016a, August 2). Russia's Angara rocket wins first commercial launch contract. Spaceflight Now. Retrieved from https://spaceflightnow.com/2016/08/02/russias-angararocket-wins-first-commercial-launch-contract/.

Clark, S. (2016b, November 3). China launches Long March 5 , one of the world's most powerful rockets. Spaceflight Now. Retrieved from https://spaceflightnow.com/2016/11/ 03/china-launches-long-march-5-one-of-the-worlds-mostpowerful-rockets/.

CNES. (n.d.). Sentinel-3. Retrieved from https://sentinel3.cnes.fr/ en/sentinel-3-0.

de Selding, P. B. (2016, January 8). SSTL developing non-toxic thruster ahead of possible European hydrazine ban. Space News. Retrieved from http://spacenews.com/sstl-developingnon-toxic-thruster-ahead-of-possible-european-hydrazineban/\#sthash.KhzY6Bsi.dpuf.

de Selding, P. B. (2013, September 24). Eurockot says it has enough usable missiles to operate through 2020. Space News. Retrieved from http://spacenews.com/37370eurockotsays-it-has-enough-usable-missiles-to-operate-through2020/\#sthash.yOqaljTN.dpuf.

Deming, J. W., Fortier, L., \& Fukuchi, M. (2002). The International North Water Polynya Study (NOW): a brief overview. Deep Sea Research II - Topical Studies in Oceanography, 49, 4887-4892.

Dumont, D., Gratton, Y., \& Arbetter, T.E. (2009). Modeling the dynamics of the North Water Polynya ice bridge. Journal of Physical Oceanography, 39, 1448-1461.

Eurockot. (n.d.). Eurockot Launch Services. Retrieved from http:// www.eurockot.com.

European Space Agency, Copernicus. (n.d.). Retrieved from http://www.esa.int/Our_Activities/Observing the Earth/ Copernicus/Overview3.

European Space Agency, Sentinel-2. (n.d.). Retrieved from https: //sentinels.copernicus.eu/web/sentinel/missions/sentinel-2.

European Space Agency, Sentinel-3B. (n.d.). Retrieved from https://earth.esa.int/web/guest/missions/esa-eo-missions/ sentinel-3.

European Space Agency, Sentinel-5P. (n.d.). Retrieved from https://sentinel.esa.int/web/sentinel/missions/sentinel-5p.

European Space Agency, Sentinel-5P Launch Campaign. (n.d.). Retrieved from http://blogs.esa.int/eolaunches/.

Fedorov, L. A. (1999). Liquid missile propellants in the former Soviet Union. Environmental Pollution, 105, 157-161.

Franckx, E. (2009). The legal regime of navigation in the Russian Arctic. Journal of Transnational Law \& Policy, 18, 327-342.

Giles, J. (2005). Study links sickness to Russian launch site. Nature, 433, 95
Graham, W. (2017, June 23). Soyuz 2-1v conducts clandestine military launch. NASAspaceflight.com. Retrieved from https://www.nasaspaceflight.com/2017/06/soyuz-2-1vconducts-clandestine-military-launch/.

Hannestad, A. (2016, June 4). Fangere: Raket rammer lige ned i vigtigt jagtområde. Politiken. Retrieved from http:// politiken.dk/udland/ECE3237878/fangere-raket-rammerlige-ned-i-vigtigt-jagtomraade/.

Heide-Jorgensen, M. P., Burt, M. L., Hansen, R. G., Nielsen, N. H., Rasmussen, M., Fossette, S., \& Stern, H. (2013). The significance of the North Water Polynya to Arctic top predators. Ambio, 42, 596-610.

Helmers, S., Ruland, R. T., \& Jacob, L. N. (2004). Epithelioid sarcoma of the thumb associated with hydrazine fuel exposure: a case report. Military Medicine, 169, 41-44.

Hønneland, G. (1999). Co-management and communities in the Barents Sea fisheries. Human Organization, 58, 397-404.

Indian Space Research Organisation. (n.d.). GSLV Mk III. Retrieved from http://www.isro.gov.in/launchers/gslv-mk-iii.

Inuit Circumpolar Council. (2016, January 19). Inuit led Pikialasorsuaq commission to study the important Northwater Polynya. Retrieved from http://inuit.org/our-work/projects/ 2016-the-pikialasorsuaq-commission/.

Japan Space Exploration Agency. (2016, November 2). "Himawari-9" lifted off for space! Launch success of $\mathrm{H}$ IIA F31. Retrieved from http://global.jaxa.jp/projects/rockets/ h2a/.

Kendall, R. \& Portanova, P. (2010, April). Launch vehicles then and now: 50 years of evolution. Crosslink Magazine. Retrieved from http://www.aerospace.org/crosslinkmag/spring2010/launch-vehicles-then-and-now-50-years-of-evolution/.

Leonard, D. (2016, April 13). Spacecraft powered by 'green' propellant to launch in 2017. Space.com. Retrieved from http://www.space.com/32567-nasa-green-propellantmission-gpim.html.

Liability Convention. (1971). Convention on international liability for damage caused by space objects. Retrieved from http://www.unoosa.org/oosa/en/ourwork/spacelaw/treaties/ introliability-convention.html.

Minjaev, A. P., Sidorov, P. I., \& Sovershaeva, S. L. (1997). Rocket-cosmic activity and health of the population. In: Siderov, P. I. (ed.), Ecology of people (pp. 13-16). Arkhangelsk: Arkhangelsk Medical Academy.

NASA. (n.d.). Green propellant infusion mission. Retrieved from https://www.nasa.gov/mission_pages/tdm/green/index.html.

Nilsen, T. (2016, June 7). Russian rocket booster fell into the Barents Sea. Independent Barents Observer. Retrieved from http://thebarentsobserver.com/en/security/2016/ 06/russian-rocket-booster-fell-barents-sea.

Norway \& USSR. (1975). Agreement on co-operation in the fishing industry. Retrieved from http://treaties.un.org/doc/ Publication/U.N.T.S./Volume\%20983/ volume-983-I-14331-English.pdf.

Norwegian Ministry of Fisheries and Coastal Affairs. (n.d.). Fisheries collaboration with Russia. Retrieved from http:// www.fisheries.no/resource_management/International_ cooperation/Fisheries_collaboration_with_Russia/.

NOTAM. (2016, June 4). Reproduced at reply \#5 in Rokot launch with Geo-IK-2 n'12L - June 4, 2016. Retrieved from https:// forum.nasaspaceflight.com/index.php?topic=39948.0.

Nunatsiaq News. (2016, September 14). North Water Polynya must be managed by Inuit: ICC commission. Retrieved from http://www.nunatsiaqonline.ca/stories/article/ 65674north_water_polynya_must_be_managed_by_inuit icc_commission/. 
Pannier, B. (2006, August 9). Kazakhstan: fallout continues from Russian rocket mishap. Radio Free Europe. Retrieved from http://www.rferl.org/a/1070442.html.

Parks Canada. (n.d.). Tallurutiup Imanga: a final boundary for Canada's largest protected area at Lancaster Sound in Nunavut. Retrieved from https://www.pc.gc.ca/en/amnc-nmca/ cnamnc-cnnmca/lancaster.

Perera, J. (1993, January 23). Rocket debris rains down on Arctic. New Scientist. Retrieved from https://www. newscientist.com/article/mg13718571-800-rocket-debrisrains-down-on-arctic/.

Pika, Airman (2016). Rockot stage 2 reentry over Greenland February 16, 2016 [Video]. Retrieved from https://www.youtube. $\mathrm{com} /$ watch? $\mathrm{v}=\mathrm{Rdd} 30 \mathrm{M} 6 \mathrm{p} 63 \mathrm{~g}$.

Radio Free Europe. (2006, August 1). Russia to compensate Kazakhstan over rocket crash. Retrieved from http://www. rferl.org/a/1070249.html.

Registration Convention. (1975). Convention on Registration of Objects Launched into Outer Space. Retrieved from http://www.unoosa.org/oosa/en/ourwork/spacelaw/treaties/ introregistration-convention.html.

RIA Novosti. (2005, May 14). In Russian north, space launch scraps offer windfall cash and threaten lives. Retrieved from https://sputniknews.com/society/2005051440064098/.

Rio Declaration. (1992). Rio declaration on environment and development. Retrieved from http://www.un.org/documents/ ga/conf151/aconf15126-1annex1.htm.

Ritz, B., Morgenstern, H., Froines, J., \& Moncau, J. (1999). Chemical exposures of rocket-engine test-stand personnel and cancer mortality in a cohort of aerospace workers. Journal of Occupational and Environmental Medicine, 41, 903-910.

Schmidt, E. W. (1984). Hydrazine and its derivatives. New York, NY: Wiley.

Shanker, T. (2008, February 21). Pentagon is confident missile hit satellite tank. New York Times. Retrieved from http://www. nytimes.com/2008/02/21/us/21cnd-satellite.html.

Sievers, E. (2003). The post-Soviet decline of Central Asia: sustainable development and comprehensive capital. London/ New York, NY: RoutledgeCurzon.

South China Morning Post. (2010, January 19). Villagers search for deadly rocket debris. Retrieved from http://www.scmp. com/article/704069/villagers-search-deadly-rocket-debris.

Space Flight News. (n.d.). Next launch of the Rockot launch vehicle postponed. Retrieved from http://spaceflights.news/ $? p=36302$.

Space Launch Report. (n.d.). Ariane 4. Retrieved from http:// www.spacelaunchreport.com/ariane4.html.

Space Launch Report. (n.d.). Rockot/Strela. Retrieved from http://www.spacelaunchreport.com/Rockot.html.

Staalesen, A. (2016, February 3). Clean up this rocket trash. Independent Barents Observer. Retrieved from http:// thebarentsobserver.com/en/ecology/2016/02/ clean-rocket-trash-our-tundra.

Stirling, I. (1980). The biological importance of polynyas in the Canadian Arctic. Arctic, 33, 303-315.
Tang, C. C. L., Ross, C. K., Yao, T., \& Dunlap, E. (2004). The circulation, water masses and sea-ice of Baffin Bay. Progress in Oceanography, 63, 183-228.

TASS. (2016, June 6). Источник: запуск трех спутников системы "Гонец" отложен на конец года. Retrieved from http://tass.ru/ kosmos/3342449.

Titan II Missile Veterans Health and Wellness. (n.d.). Retrieved from https://sites.google.com/site/ titan2vetshealthandwellness/home.

Tremblay, J. -É., Gosselin, M., Hobson, K. A., Michel, C., Gratton, Y., \& Price, N. M. (2006). Bloom dynamics in early opening waters of the Arctic Ocean. Limnology \& Oceanography, 51, 900-912.

Turebekova, A. (2015, August 14). Kazakh cosmonaut's flight is profitable for country, head of Kazcosmos says. Astana Times. Retrieved from http://astanatimes.com/2015/08/ kazakh-cosmonauts-flight-is-profitable-for-country-head-ofkazcosmos-says/.

Turner, M. J. L. (2009). Rocket and spacecraft propulsion: principles, practice and new developments. Berlin/Heidelberg: Springer.

UNCLOS. (1982). United Nations Convention on the Law of the Sea. Retrieved from http://www.un.org/depts/los/convention agreements/texts/unclos/UNCLOS-TOC.htm.

UNDP. (2004). Environment and development nexus in Kazakhstan. \#UNDPKAZ 06. Almaty. United Nations Development Program. Retrieved from https://www.thegef.org/sites/default/ files/ncsa-documents/2147-22347.pdf.

United Nations Treaty Series. (1977). Acceptance of the European Space Agency of the Convention on the International Liability for damage caused by space objects. United Nations Treaty Series, 1039, 446.

Vassilieva, M. (2013, August 7). Russians say space rocket debris is health hazard. BBC News. Retrieved from http:// www.bbc.com/news/world-europe-19127713.

Vienna Convention on the Law of Treaties. (1969). Retrieved from https://treaties.un.org/doc/publication/unts/volume\% 201155/volume-1155-i-18232-english.pdf.

Weber, B. (2016a, June 3). Canada says it didn't get enough warning about a Russian rocket stage that will splash down in Arctic. Canadian Press. Retrieved from http://news.nationalpost.com/news/canada/ canada-says-it-didnt-get-enough-warning-about-a-russianrocket-stage-that-will-splash-down-in-arctic.

Weber, B. (2016b, June 3). Inuit angered by Russian rocket splashdown in the Arctic. Canadian Press. Retrieved from http://www.theglobeandmail.com/news/national/inuitangered-by-russian-rocket-splashdown-in-the-arctic/ article30273826/.

WWF Greenland. (2015). Rapid assessment of circumArctic ecosystem resilience (RACER). The North Water Polynya. Retrieved from http://awsassets.wwfdk.panda.org/ downloads/racer_north_water_polynya.pdf.

Zak, A. (2005, October 8). Orbital ocean explorer perishes in Arctic after botched launch. Russian Space Web. Retrieved from: http://www.russianspaceweb.com/rockot.html. 